\title{
Analytical Method to Monitor Industrial Pickling Baths Initially Constituted by $\mathrm{HF}, \mathrm{HNO}_{3}$
}

\author{
Brigitte Dustou1, Laure Latapie ${ }^{1 *}$, Fabien Chauvet ${ }^{1}$, Jean-Michel Bergerat ${ }^{2}$, Theodore Tzedakis ${ }^{1 \#}$ \\ ${ }^{1}$ LGC UMR CNRS 5503, Université de Toulouse III-Paul Sabatier, Toulouse, France \\ ${ }^{2}$ Airbus, Campus 2-Building B23-Module 04-Room 0411, 1 Rond-Point Maurice Bellonte, Blagnac, France \\ Email: *latapie@chimie.ups-tlse.fr, "tzedakis@chimie.ups-tlse.fr
}

How to cite this paper: Dustou, B., Latapie, L., Chauvet, F., Bergerat, J.-M. and Tzedakis, T. (2017) Analytical Method to Monitor Industrial Pickling Baths Initially Constituted by $\mathrm{HF}, \mathrm{HNO}_{3}$. Journal of Analytical Sciences, Methods and Instrumentation, 7, 116-135.

https://doi.org/10.4236/jasmi.2017.74009

Received: October 18, 2017

Accepted: December 26, 2017

Published: December 29, 2017

Copyright $\odot 2017$ by authors and Scientific Research Publishing Inc. This work is licensed under the Creative Commons Attribution International License (CC BY 4.0).

http://creativecommons.org/licenses/by/4.0/

\begin{abstract}
The present study couples the acid/basis titration and the ICP analysis in order to monitor the concentrations of nitric and hydrofluoric acids, and presents into baths used to pickle alloys of titanium or stainless steel, largely employed in the aeronautic industry. The pickling of the alloys releases various metallic cations able to react with $\mathrm{HF}$ in order to lead to metal-fluoride complexes and free $\mathrm{H}^{+}$, the last being able to react with the basis. In this study, it was determined: the most significant correlations providing the number of the protons released by the complexation of the metallic cation by the fluoride. The proposed method based on: 1) these correlations; 2) the titration $\mathrm{pH}$ $=\mathrm{f}\left(\mathrm{V}_{\mathrm{KOH}}\right)$ curves; and 3$)$ the content of metallic cations determined by ICP, enables the monitoring of the content of $\mathrm{HNO}_{3}$ and $\mathrm{HF}$ into the pickling bath. Assuming that one bath was used for one type of alloy (alloys of Titanium for example, or alloys of stainless steel), then the proposed method appears providing reliable concentration values of both acids as well as metallic cations.
\end{abstract}

\section{Keywords}

Pickling Bath Monitoring, Mix $\mathrm{HF} / \mathrm{HNO}_{3}$ Titration, Fluoride-Metallic Cations Complexation, Titanium Alloys Pickling, Stainless Steel Alloys Pickling

\section{Introduction, Objectives of the Study-Brief Bibliography}

The aeronautic industry uses various alloys of stainless steel, or titanium to manufacture aircraft's elements, typical compositions of which were indicated in Table 1.

The elaborated elements must be pickled before their surface conditioning or treatment [1] and various type of bath were involved. The commonly used pickling solution are aqueous mixtures containing $\mathrm{HNO}_{3}(3$ to $6 \mathrm{M}$ ) and $\mathrm{HF}$ (0.5 to 2 
M) ([2] [3] [4] [5]), which could also be used to pick other metals such as silicon [6]. Several studies deal with the oxidation of these alloys and various reactions were proposed for the oxidation of their constituting metals.

Concerning titanium alloys pickled by HF alone, studies achieved by Sutter

[3] [5], conclude that oxidation takes place according to the reaction (R1):

$$
2 \mathrm{Ti}+6 \mathrm{HF} \rightarrow 2 \mathrm{Ti}^{3+}+6 \mathrm{~F}^{-}+3 \mathrm{H}_{2}
$$

Then, oxidation of $\mathrm{Ti}^{3+}$ by the atmospheric oxygen occurs, leading to $\mathrm{Ti}^{(\mathrm{IV})}$ complexed by the fluoride ions in excess. Say [4] proposes a similar attack reaction for the pickling of the alloy TB (Table 1), by HF (R2). Nevertheless, attack by HF alone is not recommended because of the hydrogen embrittlement of the alloy:

$$
\mathrm{Ti}+6 \mathrm{HF} \rightarrow \mathrm{H}_{2} \mathrm{TiF}_{6}+2 \mathrm{H}_{2}
$$

In general, pickling was not performed using nitric acid alone because it releases passivated oxides or others products which cause the pickling to be stopped:

$$
\mathrm{Ti}+2 \mathrm{HNO}_{3} \rightarrow \mathrm{TiO}_{2 \text { (passivating) }}+2 \mathrm{HNO}_{2}
$$

To avoid passivation or hydrogen embrittlement, several authors suggest to pickl using the mixture $\mathrm{HF} / \mathrm{HNO}_{3}$. For titanium alloys, Tongwen [7] proposes the reaction (R4) followed by the side reaction (R5) which releases $\mathrm{H}_{2} \mathrm{TiF}_{6}$ :

$$
\begin{gathered}
3 \mathrm{Ti}+12 \mathrm{HF}+6 \mathrm{HNO}_{3} \rightarrow 3 \mathrm{TiF}_{4}+3 \mathrm{NO}+3 \mathrm{NO}_{2}+9 \mathrm{H}_{2} \mathrm{O} \\
\mathrm{TiF}_{4}+2 \mathrm{HF} \rightarrow \mathrm{H}_{2} \mathrm{TiF}_{6}
\end{gathered}
$$

However bibliography also reveals the simpler reaction (R6):

$$
\mathrm{Ti}+6 \mathrm{HF}+4 \mathrm{HNO}_{3} \rightarrow \mathrm{H}_{2} \mathrm{TiF}_{6}+4 \mathrm{H}_{2} \mathrm{O}+4 \mathrm{NO}_{2}
$$

Note that $\mathrm{H}_{2} \mathrm{TiF}_{6}$ is assumed to be a strong di-acid, able 1) to dissociate to $\mathrm{TiF}_{6}^{2-}+2 \mathrm{H}^{+}$and 2) to give various equilibria leading $\mathrm{TiF}_{4}, \mathrm{TiF}_{5}^{-}$, or $\mathrm{TiF}_{6}^{2-}$ as function of the hydrofluoric acid concentration. Moreover, its corresponding salt $\left(\mathrm{K}_{2} \mathrm{TiF}_{6}\right)$ appears to be solid in aqueous media as claimed by Mecaprotec company [8], which processes to the pickling bath regeneration by addition of $\mathrm{KF}$ according to the reaction (R7):

$$
2 \mathrm{KF}+\mathrm{H}_{2} \mathrm{TiF}_{6} \rightarrow \mathrm{K}_{2} \mathrm{TiF}_{6 \searrow}+2 \mathrm{HF}
$$

Similar reactions and also complexes between iron and fluoride occur during the pickling of stainless steel alloys by $\mathrm{HF} / \mathrm{HNO}_{3}$ bath. Hermoso et al. [9] study the recovery of iron and chromium from pickling baths by precipitation, keeping nickel in solution. Authors report on obtained crystals of $\mathrm{K}_{2} \mathrm{FeF}_{5}$ and $\mathrm{CrF}_{3}$, with a little fraction of other oxides and fluorides phases at $60^{\circ} \mathrm{C}-65^{\circ} \mathrm{C}, \mathrm{pH}$ $4.1-4.2$.

Galvez et al. [10] claim that fluoride-metal complexes with high stabilization constants appear during the pickling of stainless steels by $\mathrm{HF} / \mathrm{HNO}_{3}$ bath. They propose a model of the various equilibria involving 25 reactions and 31 species, and conclude that $\mathrm{FeF}_{3}, \mathrm{CrF}^{2+}$ and $\mathrm{Ni}^{2+}$ are the main metallic forms in the solu- 
tion.

The rate of the pickling and the state of the surface of the alloys after treatment are strongly conditioned by the acids concentrations ratio that is why this ratio must be monitored. Empirical operations are often employed to know if it is required to replace the bath: typically optical observation of the state of the surface of the element (after pickling) often constitutes the criterion. Furthermore, the pickling rate determined on metallic-calibrated-specimens constitutes also another criterion. Besides, studies carried out by Sutter [3] on the titanium pick in $\mathrm{HNO}_{3} / \mathrm{HF}$ bath show that the pickling rate strongly decreases for $[\mathrm{HF}] /[\mathrm{Ti}]<5.4$ and the bath becomes inoperative for $[\mathrm{HF}] /[\mathrm{Ti}]<1.9$. The authors claim that the oxidation leads to $\mathrm{TiF}_{\mathrm{n}}{ }^{(\mathrm{n}-4)-}$, a specie able to be hydrolyzed to oxygenated complexes releasing HF, according to (R8):

$$
\mathrm{TiF}_{6}^{2-}+\mathrm{H}_{2} \mathrm{O} \rightarrow \mathrm{TiF}_{4} \mathrm{OH}^{-}+\mathrm{HF}+\mathrm{F}^{-}
$$

The bibliography shows various sophisticated analytical techniques which claim the monitoring of the concentrations of a mixture of $\mathrm{HF}$ and $\mathrm{HNO}_{3}$. Raman (Kang et al. [11]) and near infrared [12] spectroscopic evaluations were proposed to detect mix of $\mathrm{HNO}_{3} / \mathrm{HF}$. However, the real selectivity and reliability of all these methods, established using model solutions, must be proved with real industrial samples, especially long life time baths susceptible to contains various metallic ions.

Acid-base titration by potentiometric detection (e.g. $\mathrm{pH}=\mathrm{f}\left(\mathrm{V}_{\text {titrating agent }}\right)$ ) is a simple and low cost and technicality analytical method, which is used by the sub-contracting operators of the aircraft industry, for the surface treatment, in order to monitor the content of acids ( $\mathrm{HF}$ and $\mathrm{HNO}_{3}$ ) in the pickling baths; however potentiometric curves were not always correctly resolute; moreover, some subcontractors (in our geographic area) report that titration of industrial baths provides erroneous results and lacks in the reliability. Typically, metallic cations produced by oxidation of the alloys, can complex with fluoride or precipitate with the hydroxide ion of the titrating basis and cause drastic errors on the determined concentration of the acids.

Coupled to the alkalimetric titration, Lindroos [13] proposes to determine the concentration of the free HF in the pickling bath by direct potentiometry $\left(\mathrm{E}_{(\mathrm{V}) / \mathrm{SCE}}\right.$ $\left.=\mathrm{a}+\mathrm{b} \log \left[\mathrm{F}^{-}\right]\right)$using a fluoride-selective electrode; however authors mentions not explained interferences with the bridge of the reference electrode. Other authors [5] [8] [10] [14] achieve confrontation of the experimental titration curves to the corresponding simulated curves (obtained assuming various complexation equilibria). Titrations of 12 synthetic pickling liquors achieved with potassium hydroxide, seems providing good agreement and low errors in concentration prediction [10]. Mean relative error claimed for metal concentrations is $0.4 \%$ for iron and nickel and $1.4 \%$ for chromium; while the mean relative error for anions is $4 \%$ for fluoride and $1 \%$ for nitrate. Authors claim that 1 ) sodium hydroxide cannot be used as titration agent [10], as sodium-fluoride ion interaction displaces equilibrium and makes singular points of titration curves to overlap; and 
2) the dissolved chromium only marginally affects the HF concentration. Note that the selectivity all these additional technics must be validated with real industrial bath and that is the main remaining problem to be solved.

The objective of this study is to propose a new method enabling reliable monitoring of the contents of both $\mathrm{HNO}_{3} / \mathrm{HF}$ acids into a real industrial bath.

First titration of simple mixture of $\mathrm{HNO}_{3} / \mathrm{HF}$ acids will be performed in order to select the appropriated media and titrating agent. Then, the effect of metallic ions (released from the alloys), on the titrating basis volume and also on the shape of the $\mathrm{pH}$-metric curve will be examined, according to two separated cases: 1) metallic ions arise from titanium alloys; and 2) ions arise from stainless steel alloys; the aim is to determine the possible interferences as well as the corresponding equations. Finally ICP measurements of the metallic ions contents into industrial baths will be performed in order to validate the proposed method.

\section{Experimental Devices, Methods and Chemicals Used}

\section{Studied alloys of titanium and steel}

The compositions (mass contents) of various types of titanium and stainless steel alloys, susceptible to be pickled, are presented in Table 1. All the metallic components are susceptible to be present into the used pickling baths under ionic form complexed or not with fluoride ions.

All chemicals were normapur products supplied by Sigma-Aldrich, and the experiments were achieved at room temperature $\left(18<\mathrm{T}\left({ }^{\circ} \mathrm{C}\right)<22\right)$.

Acid-base titrations were achieved using the Metrohm automatic titrator "Toledo 888". The $\mathrm{pH}$ was monitored using a combined glass electrode specific of the $\mathrm{H}^{+}$. When the titration was carried out in organic solvent, the $\mathrm{pH}$ probe used is an LL-solvotrode, immersed in $\mathrm{LiCl}$ saturated ethanol. For titrations performed in water, an Ecotrode Plus from Metrohm (membrane glass type $\mathrm{KCl}=3 \mathrm{~mol} / \mathrm{L}$, Internal reference electrode type $\mathrm{Ag} / \mathrm{AgCl} / \mathrm{KCl}$ saturated water), was used.

The titrating agent volume at the neutralization, was read at the inflexion point of the $\mathrm{pH}=\mathrm{f}$ (volume) curve (simple and derivative). Between each titration, in order to remove possible deposit from both glass membrane and porous ceramic of the reference electrode, the probe has been cleaned with demineralized water and then by the appropriated solvent. For baths with high contents in cations, at the end of the titration, due to large quantity of deposit, the electrode has been immersed in water under agitation during 10' and then stored in $\mathrm{LiCl}$ electrolyte (in the appropriated solvent). To have an operative electrode, its calibration procedure must be performed, using standard rules and provider's recommendations. Due to the possible damages of the electrode by HF and/or by solid deposits, the calibration step must be regularly performed (as a function of the titrations number, between 1 calibration per day and 1 per week).

Titration of the cationic species contained into the alloys were achieved by 
Table 1. Contents of titanium and stainless steel alloys used in the aeronautic industry and examined in the present study. Values provided by the suppliers and checked by ICP.

\begin{tabular}{|c|c|c|c|c|c|c|c|c|c|c|c|c|}
\hline \multirow{2}{*}{ Alloy abbreviated name } & \multicolumn{12}{|c|}{ Metallic specie (mass percent) } \\
\hline & $\mathrm{Ti}$ & $\mathrm{V}$ & $\mathrm{Al}$ & Mo & $\mathrm{Zr}$ & $\mathrm{Nb}$ & Sn & $\mathrm{Cr}$ & $\mathrm{Fe}$ & $\mathrm{Ni}$ & $\mathrm{Cu}$ & Others \\
\hline TA & $\sim 99$ & & & & & & & & & & & $<1$ \\
\hline TB & $\sim 89$ & $\sim 4$ & $\sim 6$ & & & & & & & & & $<1$ \\
\hline TC & $\sim 79$ & $\sim 5$ & $\sim 5$ & $\sim 5$ & $<1.5$ & $<1.5$ & & $\sim 3$ & & & & $<1$ \\
\hline $\mathrm{TD}$ & $\sim 85$ & & $\sim 6$ & $\sim 2$ & $\sim 4$ & & $\sim 2$ & & & & & $<1$ \\
\hline IA & & & & & & & & 17 to 19 & 60 to 70 & 10 to 20 & & \\
\hline IB & & & & & & & & 14 to 15 & 70 to 78 & 4 to 6 & 2.5 to 4.5 & \\
\hline
\end{tabular}

Table 2. Acid-Base information concerning the species contained in the pickling baths involved in the present study.

\begin{tabular}{|c|c|c|c|c|}
\hline Species Solvent & Water & Ethanol & Acetone & Remarks \\
\hline $\mathrm{HF}$ & 3.1 & 5.0 & $\sim 5.5$ & Acidity decrease in organic solvents \\
\hline $\mathrm{HNO}_{3}$ & -1.0 & -1.0 & $\sim-1$ & Strong acid in the examined solvents \\
\hline $\begin{array}{l}\text { Metallic cations arising from alloys } \\
\text { indicated in Table } 1 .\end{array}$ & \multicolumn{4}{|c|}{$\begin{array}{l}{ }^{\star} \text { In absence of complexing ligands, all the cations could react with bases for } \mathrm{pH} \text { ranges from } 2 \text { to } 8 \text {. } \\
{ }^{\star} \text { The acidic behavior of the cations is strongly dependent } 1 \text { ) of their complexation, mainly by the fluo- } \\
\text { ride ion, and 2) by the media used. }\end{array}$} \\
\hline
\end{tabular}

inductive coupling plasma. (ICP-OES, ULTIMA 2-HORIBA, nebulizer chamber in Teflon).

\section{Results and Discussion}

\subsection{Selection of the Appropriated Basis and Solvent for the Titration of the Mixture of $\mathrm{HNO}_{3} / \mathrm{HF}$}

The industrial pickling bath contains initially $\mathrm{HNO}_{3} / \mathrm{HF}$ at various concentrations; we choose pickling baths containing initially these acids under the following concentrations: $3<\mathrm{HNO}_{3(\mathrm{M})}<5$ and $0.5<\mathrm{HF}_{(\mathrm{M})}<1.5$.

Various species could be used as titrating basis: $\mathrm{NaOH}, \mathrm{KOH}$, tetrabutyl-ammonium hydroxide/TBAOH, amines. To avoid toxicity risks, the amine type bases will not be considered. $\mathrm{KOH}, \mathrm{NaOH}$ and Tetrabutyl ammonium hydroxide (TBAOH)) were examined here in order to select the more appropriated. Each one exhibit advantages and drawbacks; for example, solubility in soda (aqueous or not) of the metallic cations is lower compared to the other bases and the produced solid species causes the fouling of the combined $\mathrm{pH}$ electrode. In a similar way various solvents were available to carry out the titrations (Table 2); as a function of the $\mathrm{pK}$ of the acid in the solvent the titration curve can be well resolute or not.

In order to have a nice separation of the volumes required to neutralize two different acids, the difference between the $\mathrm{pK}$ of these acids must be at the least two units. Table 2 provides the $\mathrm{pK}$ of $\mathrm{HF}$ and $\mathrm{HNO}_{3}$ in various solvents, and 
clearly shows that, for the HF titration, it is better to operate in ethanol (or acetone) than in water ( $\mathrm{pK}_{\text {ethanol }}>\mathrm{pK}_{\text {water }}$ ).

However, whatever the media, the presence of metallic cations (complexed or not) is able to disturb the neutralization curve in the same $\mathrm{pH}$ range, because: 1) hydroxides of these metallic cations could precipitate and 2) these cations, complexe with fluoride and could lead to some strong acids neutralized simultaneously.

In order to select both the solvent and the basis, each acid was titrated separately and then the titration of their mixture (e.g. the pickling bath) was performed. In the light of the obtained results (curves $\mathrm{pH}=\mathrm{f}\left(\mathrm{V}_{\text {basis }}\right)$, Figure 1) titration using aqueous solution of soda (Figure 1(a)) was rejected, because the low resolution of the curve obtained with the mixture of both acids. This curve does not enable the determination of both concentrations separately.

The same titrations were performed using $\mathrm{KOH}$ (Figure $1(\mathrm{~b})$ ) or $\mathrm{TBAOH}$ (Figure 1(c)) into ethanol, and the obtained curves exhibit nicely resolute waves for each acid, consequently both $\mathrm{KOH}$ and $\mathrm{TBAOH}$, in ethanol, could be selected to pursue analyses. According to the Table 2, acetone is the solvent expected to provides the best results because the highest $\mathrm{pK}$ differences $\left(\mathrm{pK}_{\text {acetone-HF }}-\mathrm{pK}_{\mathrm{wa}}\right.$ ter-HF $=2.4)$.
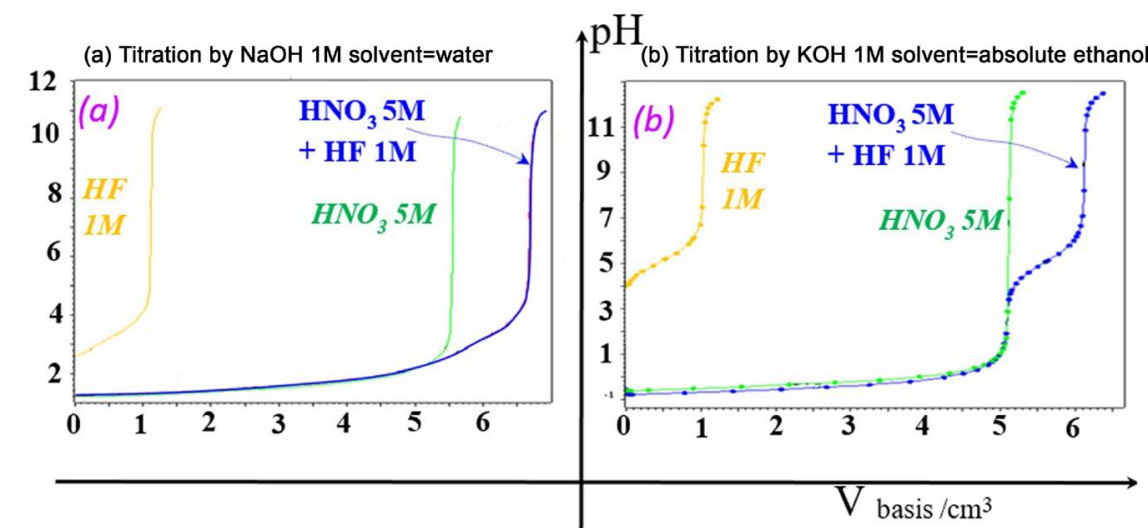

(c) Titration by TBAOH $0.1 \mathrm{M}$ solvent=absolute ethanol
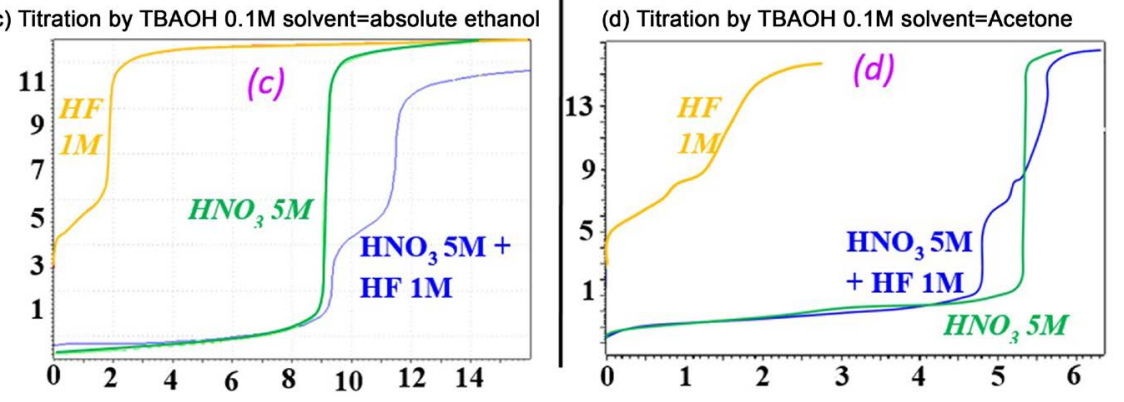

Figure 1. Titration, by various bases and in various solvents, of the acids $\mathrm{HNO}_{3} / \mathrm{HF}$ alone or in mixture. Metrohm Toledo 888 titrator, solvotrode, room temperature, agitation. For titrations by $\mathrm{KOH}$ or $\mathrm{NaOH}((\mathrm{a}),(\mathrm{b}))$ : Quantity of the solution to be analyzed: $1 \mathrm{~mL}$; Final volume of the mixture to be titrated: $50 \mathrm{~mL}$ (completed using the selected solvent); For titrations by Tetrabutyl ammonium hydroxide (TBAOH ((c), (d)): Quantity of the solution to be analyzed: $0.2 \mathrm{~mL}$; Final volume of the mixture to be titrated: $50 \mathrm{~mL}$ (completed using the selected solvent. 
However, titration of HF using acetone (Figure 1(d)) leads to a curve containing two "low resolution" waves, meaning a decomposition or some complexation/ reaction leading to two different acids ( $\mathrm{HF}, \mathrm{HF}_{2}^{-}$, or some other adducts). Consequently, the use of acetone will be excluded.

To sum up both $\mathrm{KOH}$ and TBAOH bases in ethanol solvent enables separated determination of the concentrations of the acids used in the pickling baths. In absence of interfering species, the first neutralization $\left(V_{\mathrm{e} 1}\right)$ is attributed to the nitric acid, while the second one (net volume $=V_{\mathrm{e} 2}-V_{\mathrm{e} 1}$, where $V_{\mathrm{e} 2}$ is the total volume measured) represents the reaction with $\mathrm{HF}$.

\subsection{Influence of Some Species Produced by the Pickling of the Alloys on the Neutralization Volumes $\left(\mathrm{pH}=\mathrm{f}\left(\mathrm{V}_{\text {basis }}\right)\right)$}

This section examine the effect of the concentration of the most abundant elements of the alloys (susceptible to be oxidized during the alloy pickling), on the neutralization waves of both $\mathrm{HF}$ and $\mathrm{HNO}_{3}$ acids. It is expected to get a better understanding of the phenomena taking place in order to propose the more reliable method enabling the monitoring of the contents of the $\mathrm{HNO}_{3}$ and $\mathrm{HF}$ acids into industrial pickling baths. In order to simplify the investigation we consider in this study baths containing both $\mathrm{HF}$ and $\mathrm{HNO}_{3}$ acids, used to pickle alloys of: 1) titanium; and 2) stainless steel.

\subsubsection{Alloys of Titanium}

1) Influence of the titanium concentration (under the form $\mathrm{H}_{2} \mathrm{TiF}_{6}$ ) on the acid-base titrations of a mixture of acids $\mathrm{HNO}_{3}, \mathrm{HF}$

The titanium is the main metal $(80 \leq$ mass percent $\leq 99)$ constitutes the titanium alloys; its cations, especially $\mathrm{Ti}^{(\mathrm{IV})}$, are able to forms acidic compounds by complexation with the fluoride anions [3] [7] [8]. This section expects to study the plausible reaction of these species by the previous selected bases $(\mathrm{KOH}$ and TBAOH in the ethanol solvent) and to determine possible interferences on the waves of the neutralization of $\mathrm{HNO}_{3}$ and $\mathrm{HF}$.

The Figure 2 exhibits the curves obtained by titration of mixtures of $\mathrm{HNO}_{3} 5$ M, HF $1 \mathrm{M}$ and $\mathrm{H}_{2} \mathrm{TiF}_{6}$, at three different concentrations, within ethanol by respectively two titrating bases: top/(i): $\mathrm{KOH} 1 \mathrm{~mol} / \mathrm{L}$; and bottom/(ii): $\mathrm{TBAOH}$ $0.1 \mathrm{~mol} / \mathrm{L}$. The curves clearly indicate a different behavior of the $\mathrm{H}_{2} \mathrm{TiF}_{6}$ acid against the titrating basis.

For titrations carried out by $\mathrm{KOH}$ (Figure $2(\mathrm{i})$ ), the obtained $\mathrm{pH}=\mathrm{f}\left(\mathrm{V}_{\mathrm{KOH}}\right)$ curve contains two neutralization waves, whatever the concentration of the $\mathrm{H}_{2} \mathrm{TiF}_{6}$; increasing this last from 0.2 to $0.6 \mathrm{M}$ cause the volume of the first neutralization (attributed to $\mathrm{HNO}_{3}$ ) to increase, confirming that the $\mathrm{H}_{2} \mathrm{TiF}_{6}$ is a strong acid, neutralized simultaneously to the $\mathrm{HNO}_{3}$. The second part of the curve in Figure 2(i), i.e. the second wave (previously attributed to the neutralization of the HF), is just shifted to the right, but the corresponding volume remains constant.

In order to determine the protons number of the $\mathrm{H}_{2} \mathrm{TiF}_{6}$ neutralized (during 

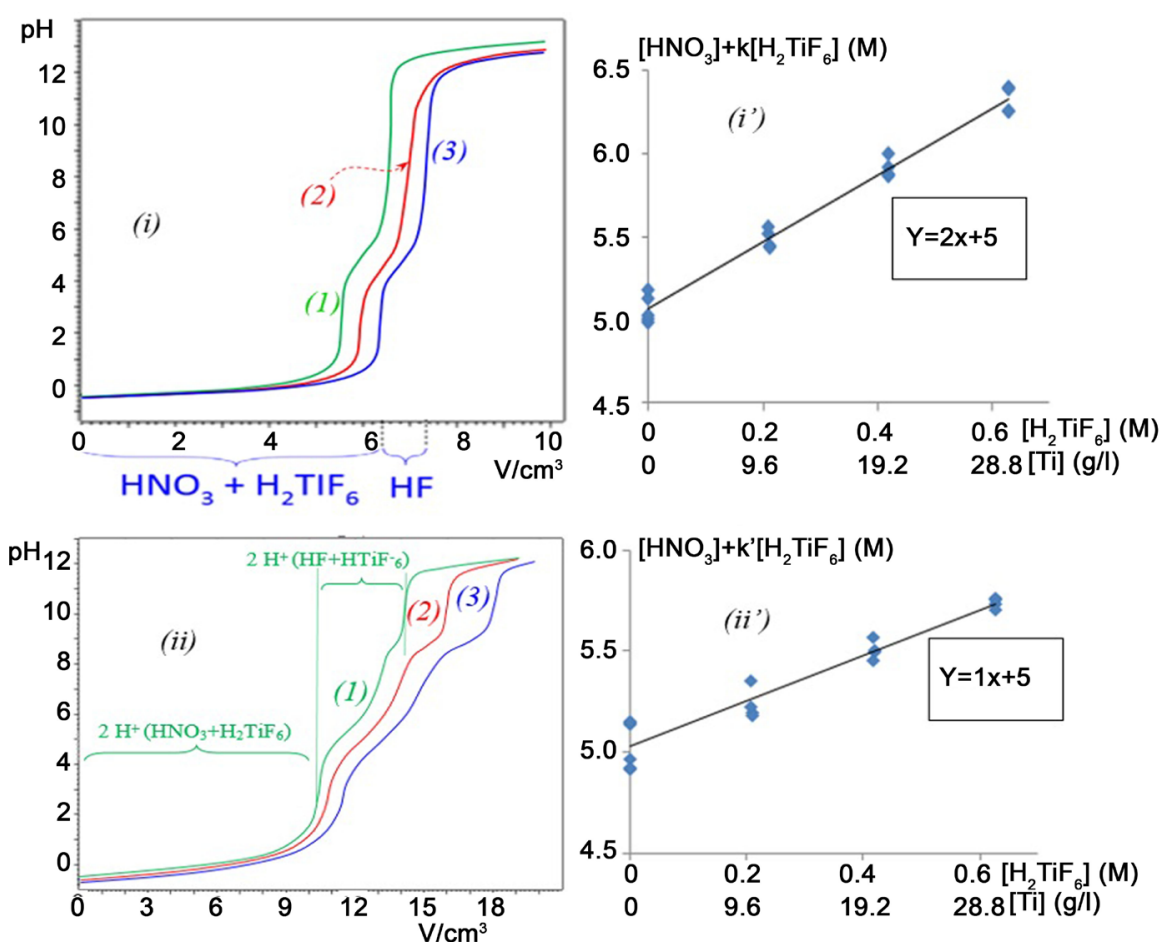

Figure 2. Titration curves of the mixture $\mathrm{HNO}_{3} 5 \mathrm{M}$, HF $1 \mathrm{M}$ and $\mathrm{H}_{2} \mathrm{TiF}_{6}$ at three different concentrations, by two titrating bases (left-top (i): $\mathrm{KOH} 1 \mathrm{~mol} / \mathrm{L}$; and left-bottom (ii): TBAOH $0.1 \mathrm{~mol} / \mathrm{L}$ ) in the absolute ethanol. $\mathrm{H}_{2} \mathrm{TiF}_{6}$ concentration: $0.21,0.42$ and $0.63 \mathrm{M}$ for respectively curves (1) green, (2) red and (3) blue curve. Room temperature, agitation, Metrohm Toledo 888 titrator, solvotrode. Left-top (i): Quantity of the solution to be analyzed: $1 \mathrm{~mL}$; Final volume of the mixture to be titrated: $50 \mathrm{~mL}$ (into ethanol). Right-top (i'): Evolution of the total acidity (deduced from the volume of the first neutralization (curve $\mathrm{i}, 1$ ) as a function of the added known-concentration of $\mathrm{H}_{2} \mathrm{TiF}_{6}$ into the mixture containing $\mathrm{HNO}_{3} 5 \mathrm{M} / \mathrm{HF} 1 \mathrm{M}$ (several solutions have been tested). Left-bottom (ii): Quantity of the solution to be analyzed: $0.2 \mathrm{~mL}$; Final volume of the mixture to be titrated: $50 \mathrm{~mL}$ (into ethanol). Right-bottom (ii'): Evolution of the total acidity (deduced from the volume of the first neutralization (curve ii, 1) as a function of the added known-concentration of $\mathrm{H}_{2} \mathrm{TiF}_{6}$ into an initial mixture containing $\mathrm{HNO}_{3} 5 \mathrm{M}$ and $\mathrm{HF} 1 \mathrm{M}$ (several solutions have been tested).

the first wave of the curve), the total acidity (deduced from the first neutralization) was plotted against the $\mathrm{H}_{2} \mathrm{TiF}_{6}$ "added" concentration in the mixture of $\mathrm{HF} / \mathrm{HNO}_{3}$ (Figure 2(i'), experiments triplicates).

A straight line, deduced from the first neutralization, describes the evolution of the total acidity against the added concentration of the $\mathrm{H}_{2} \mathrm{TiF}_{6}(\mathrm{e} 1)$ :

$$
\left(\left[\mathrm{HNO}_{3}\right]+k \times\left[\mathrm{H}_{2} \mathrm{TiF}_{6}\right]\right)=5.07+2.0 \times\left[\mathrm{H}_{2} \mathrm{TiF}_{6}\right] ; R^{2}=0.98
$$

The observed slope is equal to 2, meaning that the $\mathrm{H}_{2} \mathrm{TiF}_{6}$ releases "two protons" which are neutralized during the first acid-base reaction; in these conditions, it behaves as a strong di-acid, neutralized in the same $\mathrm{pH}$ range as nitric acid $\left(\mathrm{HNO}_{3} \times 1 \mathrm{H}^{+}\right.$and $\left.\mathrm{H}_{2} \mathrm{TiF}_{6} \times 2 \mathrm{H}^{+}\right)$. In absence of another interfering species, the volume of the second neutralization (second wave) can be used to determine the hydrofluoric acid concentration. 
Different results were obtained when titrations were carried out by TBAOH. The $\mathrm{pH}=\mathrm{f}\left(\mathrm{V}_{\text {тваOH }}\right)$ curves (Figure 2(ii)) contain three neutralization waves (instead two for the titration with $\mathrm{KOH}$ ). Increasing the concentration of the $\mathrm{H}_{2} \mathrm{TiF}_{6}$ from 0.2 to $0.6 \mathrm{M}$ appears to affect the volume of the three neutralizations. As previously, analysis of the evolution of the first neutralization wave versus the added concentration of the $\mathrm{H}_{2} \mathrm{TiF}_{6}$ was achieved and the results were reported in Figure 2(ii'); a straight line describes the evolution of the total acidity against the added $\left[\mathrm{H}_{2} \mathrm{TiF}_{6}\right]$ and it obeys to Equation (e2):

$$
\left(\left[\mathrm{HNO}_{3}\right]+k^{\prime} \times\left[\mathrm{H}_{2} \mathrm{TiF}_{6}\right]\right)=5.03+1.1 \times\left[\mathrm{H}_{2} \mathrm{TiF}_{6}\right] ; R^{2}=0.93
$$

The observed slope, very close to 1 , means that one proton of the $\mathrm{H}_{2} \mathrm{TiF}_{6}$ reacts with $\mathrm{TBAOH}$, simultaneously to the $\mathrm{HNO}_{3}$, during the first neutralization. $\mathrm{H}_{2} \mathrm{TiF}_{6}$ behaves in these conditions, as a strong mono-acid.

Comparison of the curves (i) and (ii) in Figure 2 enables to conclude that the salt $\mathrm{K}_{2} \mathrm{TiF}_{6}$ (solid as claimed by Mecaprotec company [8]) is more stable than the $(\mathrm{TBA})_{2} \mathrm{TiF}_{6}$. Concerning the second and the third neutralization-waves of the curves (Figure 2(ii)), it is not obvious to attribute them to the HF or $(\mathrm{TBA})_{1}(\mathrm{H})_{1} \mathrm{TiF}_{6}$; indeed, both volumes increase when the concentration of the added $\mathrm{H}_{2} \mathrm{TiF}_{6}$ increase from 0.2 to $0.6 \mathrm{M}$, but the resolution remains low and does not enable a correct attribution of the equivalent volumes of the TBAOH.

To sum up, when titration of a pickling bath containing the mixture of $\mathrm{HF} / \mathrm{HNO}_{3}$ and $\mathrm{H}_{2} \mathrm{TiF}_{6}$ was carried out by TBAOH, the curve exhibits three neutralization waves, the first one concerns both $\mathrm{HNO}_{3}\left(\times 1 \mathrm{H}^{+}\right)$and $\mathrm{H}_{2} \mathrm{TiF}_{6}\left(\times 1 \mathrm{H}^{+}\right)$, while the second and third were not rigorously identified. Besides, because the $\mathrm{TBAOH}$ is a relatively unstable basis and it decomposes in contact with the air/ moisture, only potash will be used in the next sections.

2) Influence of the aluminum concentration $\left(\mathrm{Al}\left(\mathrm{NO}_{3}\right)_{3}, 9 \mathrm{H}_{2} \mathrm{O}\right)$ on the acid-base titrations of a mixture of acids $\mathrm{HNO}_{3} / \mathrm{HF}$

The aluminum is another metal contained into the titanium alloys (Table 1). $\mathrm{Al}^{(\mathrm{III})}$ is also known to be complexed by fluoride ions [15] and this section expects to examine the plausible reaction of the complex $\mathrm{Al}^{(\mathrm{III})} /$ fluoride (produced by the pickling of titanium alloys) with $\mathrm{KOH}(0.85 \mathrm{M}$ in the ethanol solvent $)$ and to determine possible interferences on the waves of the neutralization of $\mathrm{HNO}_{3}$ and HF. Nona-hydrated salt of aluminum nitrate was added, into the pickling bath $\mathrm{HNO}_{3} / \mathrm{HF}$, at various mass concentration in agreement with the aluminum contents into the pickling baths (Figure $3(\mathrm{a})$ ) $0.03 \mathrm{M} / 0.75 \mathrm{~g} / \mathrm{L}$ to $0.085 \mathrm{M} / 2.28 \mathrm{~g} / \mathrm{L}$.

The $\mathrm{pH}=\mathrm{f}\left(\mathrm{V}_{\mathrm{KOH}}\right)$ curves (a) show that the volume required for the first neutralization $\left(V_{\mathrm{e} 1}\right)$ increases with the addition of aluminum nitrate, while the volume used for the $2^{\text {nd }}$ neutralization decreases and the overall volume of $\mathrm{KOH}$ to neutralize the mixture remains constant! The total acidity neutralized for each wave was plotted versus the aluminum nitrate added quantity (Figure 3(a1) and Figure 3(b1)).

A linear evolution was observed for both the first and the second neutralization, and the obtained correlations were indicated in the caption of the Figure 3. 


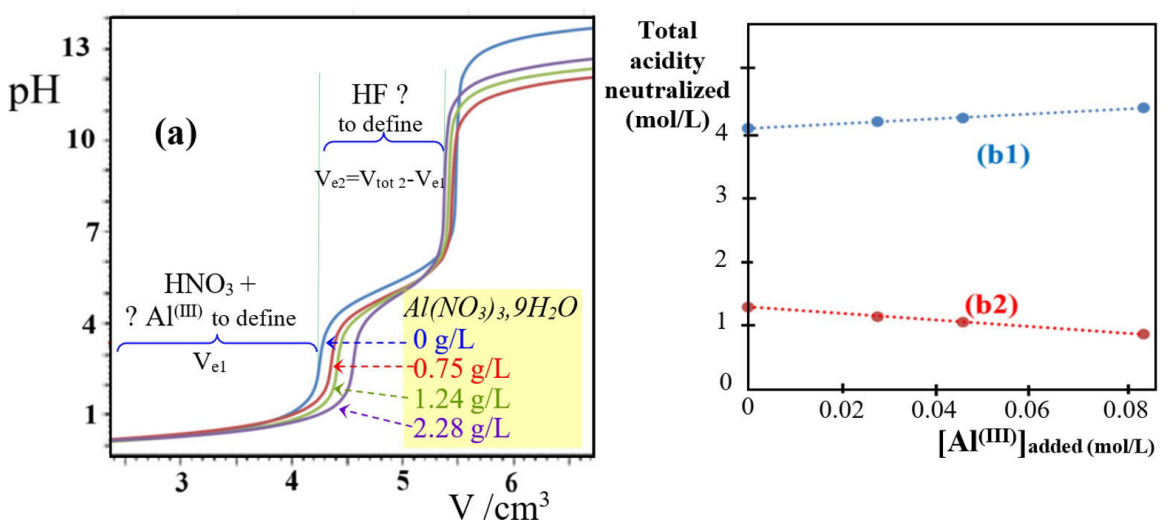

Figure 3. Titration curves of the mixture $\mathrm{HNO}_{3} 4 \mathrm{M}$, $\mathrm{HF} 1.3 \mathrm{M}$ and $\mathrm{Al}\left(\mathrm{NO}_{3}\right)_{3}, 9 \mathrm{H}_{2} \mathrm{O}$, by $\mathrm{KOH}(0.85 \mathrm{M})$ in ethanol. Room temperature, agitation, Metrohm Toledo 888 titrator, solvotrode. Quantity of the solution to be titrated: $1 \mathrm{~mL}$, diluted using ethanol into a final volume of $50 \mathrm{~mL}$. (a) $\mathrm{pH}=\mathrm{f}\left(\mathrm{V}_{\mathrm{KOH}}\right)$ curves obtained at three different concentrations of $\mathrm{Al}\left(\mathrm{NO}_{3}\right)_{3}, 9 \mathrm{H}_{2} \mathrm{O}$. (b1) Total acidity determined from the $\mathrm{I}^{\text {st }}$ wave $\left(V_{\mathrm{el}}\right)$ :

$\left[\mathrm{HNO}_{3}\right]+\lambda \times\left[\mathrm{Al}^{(\mathrm{III})}\right]=4.02+3.7 \times\left[\mathrm{Al}^{(\mathrm{III})}\right] R^{2}=0.99$ (e3). (b2) Total acidity determined from the $\mathrm{II}^{\mathrm{d}}$ wave $\left(V_{\mathrm{e} 2}\right):[\mathrm{HF}]+\mu \times\left[\mathrm{Al}^{(\mathrm{III})}\right]=1.26-3.7 \times\left[\mathrm{Al}^{(\mathrm{III})}\right] R^{2}=0.99$ (e4).

The slope value of 3.7 was obtained for the first neutralization, while the value of -3.7 was found for the second neutralization.

The following reactions could be proposed:

$$
\begin{aligned}
& (\beta / 3) \mathrm{Al}\left(\mathrm{NO}_{3}\right)_{3}+(\beta) \mathrm{HF}(\text { or }(2 \beta) \mathrm{HF}) \\
& \rightarrow(\beta) \mathrm{HNO}_{3}+(\beta / 3) \mathrm{AlF}_{3}\left(\text { or }(\beta / 3) \mathrm{H}_{3} \mathrm{AlF}_{6}\right)
\end{aligned}
$$

$\mathrm{I}^{\text {st }}$ neutralization:

$$
\begin{aligned}
& \varphi\left(\mathrm{HNO}_{3}\right)_{\text {initial }}+\beta\left(\mathrm{HNO}_{3}\right)_{\text {from reaction }(9)}+(\varphi+\beta) \mathrm{KOH} \\
& \rightarrow(\varphi+\beta) \mathrm{H}_{2} \mathrm{O}+(\varphi+\beta) \mathrm{KNO}_{3}
\end{aligned}
$$

$\mathrm{II}^{\mathrm{d}}$ neutralization:

$$
\begin{aligned}
& \left\{\lambda_{\text {initial }}-\beta(\text { or }(2 \beta))\right\} \mathrm{HF}+\left\{\lambda_{\text {initial }}-\beta\right\} \mathrm{KOH} \\
& \rightarrow\left\{\lambda_{\text {initial }}-\beta\right\} \mathrm{H}_{2} \mathrm{O}+\left\{\lambda_{\text {initial }}-\beta\right\} \mathrm{KF}
\end{aligned}
$$

One aluminum complexes 3 fluorides and provides 3 nitric acids that explains the decreases of the second neutralization volume (HF) and the increases of the first one $\left(\mathrm{HNO}_{3}\right)$.

Note that if $\mathrm{H}_{3} \mathrm{AlF}_{6}$ is formed (R9), there is no change in the volume of $\mathrm{KOH}$ required for both neutralizations. Indeed, in this scenario, the 3 additional HF consumed were compensated by the 3 protons released by $\mathrm{H}_{3} \mathrm{AlF}_{6}$ which appears here as a weak acid, similar to HF.

Concerning the other metallic cations susceptible to be released by the titanium alloys (Table 1 ) into the pickling bath, their effect on the volume of the titrating basis required for the neutralization, was not investigated in the present study. Indeed, their overall mass content does not exceed 5\%, and the most important are: $\mathrm{V}(\sim 5 \%, \mathrm{~d}=5.9)$, Mo $(\sim 5 \%, \mathrm{~d}=10.2)$ and $\mathrm{Cr}(\sim 3 \%, \mathrm{~d}=7)$; taking 
into account their high density, compared to this of titanium $(\mathrm{d}=4.5)$, we can conclude that their molar composition is relatively low $(<4 \%)$ and can be neglected for the determination of $\mathrm{HF}$ and $\mathrm{HNO}_{3}$ concentrations of the titanium pickling baths.

To conclude, when the pickling bath contains cations such as $\mathrm{Ti}^{(\mathrm{IV})}$ or/and $\mathrm{Al}^{(\mathrm{III})}$ it arises their complexation by fluoride ions, reactions releasing protons which behave as strong acid and neutralize during the first wave (simultaneously to $\mathrm{HNO}_{3}$ ). Consequently we can conclude that the first neutralization wave in the curve $\mathrm{pH}=\mathrm{f}\left(\mathrm{V}_{\text {titrating basis }}\right)$ concerns, at the least three species: nitric acid, titanium and aluminum adducts.

The second neutralization volume, (corresponding to the HF in the case of an initial pickling bath) is also affected by the presence of the cations released by the alloys pickling, especially aluminum.

So it appears difficult to determine, by the use of single potentiometric titrations alone, the concentration of both acids $\left(\mathrm{HNO}_{3}\right.$ and $\left.\mathrm{HF}\right)$ into a solution which has been "largely" used to pickle titanium alloys. ICP was employed to determine the concentrations of $\mathrm{Al}$ (III) and $\mathrm{Ti}$ (IV), and we propose following way for the monitoring of the concentration of $\mathrm{HNO}_{3}$ and $\mathrm{HF}$ into the pickling bath:

To access to the nitric acid concentration, the Equation (e5) must be used: moles of $\mathrm{HNO}_{3}$ into the pickling bath titrated volume $=$ moles of $\mathrm{KOH}$ used in the first neutralization $\left(V_{\mathrm{e} 1}\right)$ $-2 \times$ moles of $\mathrm{Ti}^{(\mathrm{IV})}$ determined by ICP

$-3 \times$ moles of $\mathrm{Al}^{(\mathrm{III})}$ determined by ICP

To access to the hydrofluoric acid concentration, the Equation (e6) must be used:

moles of HF into the pickling bath titrated volume

$=$ moles of $\mathrm{KOH}$ used in the II ${ }^{\mathrm{d}}$ neutralization $\left(V_{\mathrm{e} 2}=V_{\mathrm{tot} 2}-V_{\mathrm{e} 1}\right)$

\subsubsection{Alloys of the Stainless Steel}

In this section we examine mixtures exclusively devoted to pickle alloys of the stainless steel. The most abundant elements of these alloys are the iron, the chromium and the nickel (Table 1). The effect of the concentration of these metallic cations on the waves of the neutralization of $\mathrm{HNO}_{3}$ and $\mathrm{HF}$ (curves $\mathrm{pH}=$ $\mathrm{f}\left(\mathrm{V}_{\text {titrating basis:KOH }}\right)$ was examined with the same objective as previously: to try to define a reliable method enabling the monitoring of the acidic contents of the industrial pickling baths initially containing these acids.

1) Influence of the iron $\mathrm{Fe}^{(I I)}$ concentration on the titration by $\mathrm{KOH}$ of the mixture " $\mathrm{HNO}_{3} / \mathrm{HF}$ "

The iron is the main metal $(60 \leq$ mass percent $\leq 80)$ constituting the stainless steel alloys. The cations released after the pickle of the alloy, especially $\mathrm{Fe}^{(\mathrm{III})}$, are able to complex with the fluoride anions to form compounds such as $\mathrm{FeF}_{3}$ or $\mathrm{H}_{3} \mathrm{FeF}_{6}[16]$. The influence of the $\mathrm{Fe}^{(\mathrm{IIII})}$ on the volume of the titrating base $(\mathrm{KOH}$ 
$1 \mathrm{M}$ in ethanol) required to neutralize $\mathrm{HNO}_{3}$ and $\mathrm{HF}$ was examined. To that end titrations of baths containing both acids were performed by adding iron(III) nitrate at various concentrations.

In the examined concentration range, the obtained curves $\mathrm{pH}=\mathrm{f}\left(\mathrm{V}_{\mathrm{KOH}}\right)$ Figure 4(a), exhibits two neutralization waves; increasing the concentration of the nitrate-iron-added cause the volume of the first neutralization (previous attributed to the $\mathrm{HNO}_{3}$ ) to increase, while, simultaneously the volume required for the second neutralization decreases. Moreover the total volume of $\mathrm{KOH}$ used for the neutralization remains constant in the examined range. Curves presented on the right (Figure 4(b1), Figure 4(b2) and Figure 4(c)) give the effect of he added iron concentration $\left(\mathrm{Fe}\left(\mathrm{NO}_{3}\right)_{3}\right)$ on the evolutions of the acidity determined from: the first (b1) or the second (b2) neutralization waves, as well as from the sum of the first neutralization wave and the "know" added iron content (c). A linear evolution was observed for all cases, the obtained slopes inform on the number of the involved "equivalent $\mathrm{H}^{+}$", in the corresponding neutralization. Thus, concerning the first neutralization wave (b1), the slope find is equal to 5.7, (considered equal to 6), means that the addition of 1 mole of $\mathrm{Fe}\left(\mathrm{NO}_{3}\right)_{3}$ leads to the creation of a number of equivalent $\mathrm{H}^{+}$which reacts and neutralizes 6 moles of the $\mathrm{KOH}$.

Simultaneously, curve (b2), concerning the second neutralization wave (and
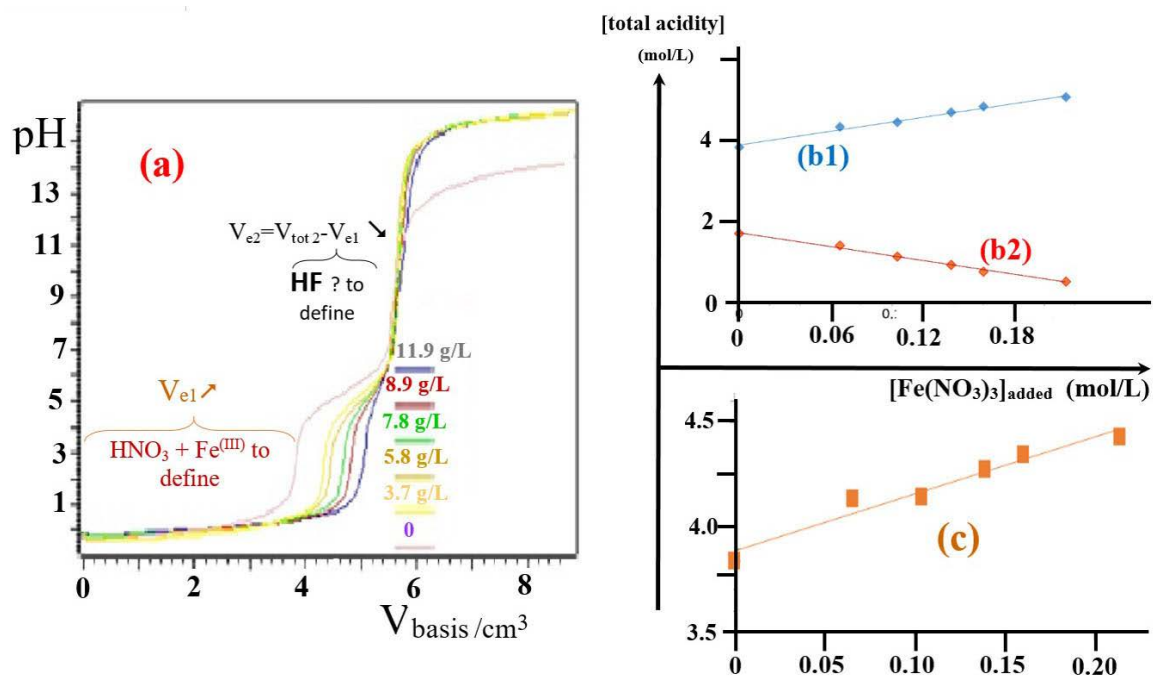

Figure 4. Acid-Base titration curves of the mixture containing $\mathrm{HNO}_{3}(3.8 \mathrm{~mol} / \mathrm{L}), \mathrm{HF}(1.7$ $\mathrm{mol} / \mathrm{L}$ ) and (nonahydrated $\left.\mathrm{Fe}\left(\mathrm{NO}_{3}\right)_{3}\right)$ at various concentrations $(\mathrm{a}) . \mathrm{KOH}(1 \mathrm{M})$ is the titrating basis present in ethanol. Room temperature, agitation, Metrohm Toledo 888 titrator, solvotrode. Quantity of the solution to be titrated: $1 \mathrm{~mL}$, diluted into a final volume of $50 \mathrm{~mL}$ (completed using ethanol). Right: effect of added $\mathrm{Fe}\left(\mathrm{NO}_{3}\right)_{3}$ concentration on the total acidity determined from: (b1) the $\mathrm{I}^{\text {st }}$ neutralization:

$\left[\mathrm{HNO}_{3}\right]+\eta *\left[\mathrm{Fe}\left(\mathrm{NO}_{3}\right)_{3}\right]=3.9+5.7 *\left[\mathrm{Fe}\left(\mathrm{NO}_{3}\right)_{3}\right] R^{2}=0.99$ (e7). (b2) the $\mathrm{II}^{\mathrm{d}}$ neutralization: $[\mathrm{HF}]+\lambda *\left[\mathrm{Fe}\left(\mathrm{NO}_{3}\right)_{3}\right]=1.7-5.7 *\left[\mathrm{Fe}\left(\mathrm{NO}_{3}\right)_{3}\right] R^{2}=0.99 \quad(\mathrm{e} 8)$. (c) both the $\mathrm{I}^{\text {st }}$ neutralization and the total added iron content $\left(V_{\mathrm{el}}-3^{*}[\mathrm{Fe}]\right)$ :

$\left[\right.$ acid j] $=3.9+2.7 *\left[\mathrm{Fe}\left(\mathrm{NO}_{3}\right)_{3}\right] R^{2}=0.96$ (e9). 
giving the evolution of the concentration of the remaining HF, after reaction with the iron nitrate) exhibits a negative slope, find equal to -5.7 , clearly shows that one molecule of iron consumes six molecules of HF. The following reaction scheme can be proposed to explain these evolutions: the iron added complexes with the fluoride of the hydrofluoric acid HF:

$$
\mathrm{Fe}\left(\mathrm{NO}_{3}\right)_{3}+6 \mathrm{HF} \rightarrow \mathrm{H}_{3} \mathrm{FeF}_{6}+3 \mathrm{HNO}_{3}
$$

Both the obtained tri-acid $\mathrm{H}_{3} \mathrm{FeF}_{6}$ and the nitric acid as well as the nitric acid initially present in the bath, react simultaneously during the first neutralization wave $\left(V_{e l}\right)$ by the basis according to:

$$
\begin{aligned}
& \mathrm{H}_{3} \mathrm{FeF}_{6}+3 \mathrm{KOH}+\left(3+a_{\text {initial }}\right) \mathrm{HNO}_{3}+\left(3+a_{\text {initial }}\right) \mathrm{KOH} \\
& \rightarrow 3 \mathrm{H}_{2} \mathrm{O}+\mathrm{K}_{3} \mathrm{FeF}_{6}+\left(3+a_{\text {initial }}\right) \mathrm{H}_{2} \mathrm{O}+\left(3+a_{\text {initial }}\right) \mathrm{KNO}_{3}
\end{aligned}
$$

Then, the neutralization of the "remaining free HF" occurs. The curve shown in the Figure 4(c), presents the evolution of the concentration of the nitric acid (obtained by subtracting at the first neutralization volume $\left(V_{e q 1}\right)$, three fold the quantity of the iron nitrate), as a function of $\mathrm{Fe}\left(\mathrm{NO}_{3}\right)_{3}$ added. The obtained slope equal to 2.7 and considered to be equal to 3 , clearly shows that one molecule of iron added in the mixture creates an equivalent number of three supplementary protons to be neutralized.

In conclusion of this section, when iron cation is added in the $\mathrm{HNO}_{3} / \mathrm{HF}$ bath, the overall neutralization volume of $\mathrm{KOH}\left(V_{\text {tot2 }}\right)$ is not affected; however both the volumes of the first and the second neutralization (respectively $V_{\mathrm{e} 1}$ and $V_{\mathrm{e} 2}$ ) were affected. Moreover direct precipitation of $\mathrm{Fe}(\mathrm{OH})_{3}$ was not observed.

From these results it can be proposed the following equations:

$$
\begin{aligned}
& \text { moles of } \mathrm{KOH} \text { used in the first neutralization }\left(V_{\mathrm{e} 1}\right) \\
& =\text { moles of } \mathrm{HNO}_{3} \text { into the pickling bath titrated volume } \\
& +6 \times \text { moles of } \mathrm{Fe}^{(\mathrm{III})} \text { introduced }
\end{aligned}
$$

moles of $\mathrm{KOH}$ used in the II ${ }^{\mathrm{d}}$ neutralization $\left(V_{\mathrm{e} 2}=V_{\mathrm{tot} 2}-V_{\mathrm{e} 1}\right)$

$=$ moles of the free HF into the pickling bath titrated volume

2) Influence of the chromium $\left(\mathrm{Cr}\left(\mathrm{NO}_{3}\right)_{3}, 9 \mathrm{H}_{2} \mathrm{O}\right)$ on the acid-base Titrations of a $\mathrm{HNO}_{3}$, $\mathrm{HF}$ pickling bath

The chromium is introduced in relatively important quantities into the stainless steel alloys $\left(14<\mathrm{Cr}_{(\text {mass \%) }}<20\right)$. The cations released after the pickle of the alloy, especially $\mathrm{Cr}^{(\mathrm{III})}$, are able to complex with the fluoride anions to form compounds such as $\mathrm{CrF}_{3}, \mathrm{CrF}_{2}^{+}$or $\mathrm{CrF}^{2+}$ [17], however the complexation constants appear to be relatively low $\left(<10^{4}\right)$; besides no information were found about complexation of $\mathrm{Cr}^{(\mathrm{VI})}$ and $\mathrm{F}^{-}$. The influence of the $\mathrm{Cr}^{(\mathrm{III})}$ on the volume of the titrating base $(\mathrm{KOH})$ required to neutralize $\mathrm{HNO}_{3}$ and $\mathrm{HF}$ was examined as previously (adding chromium nitrate at various concentrations, chosen in function of the weight $\%$ of $\mathrm{Cr}$ into the stainless steels), and the results were presented in Figure 5(a). 


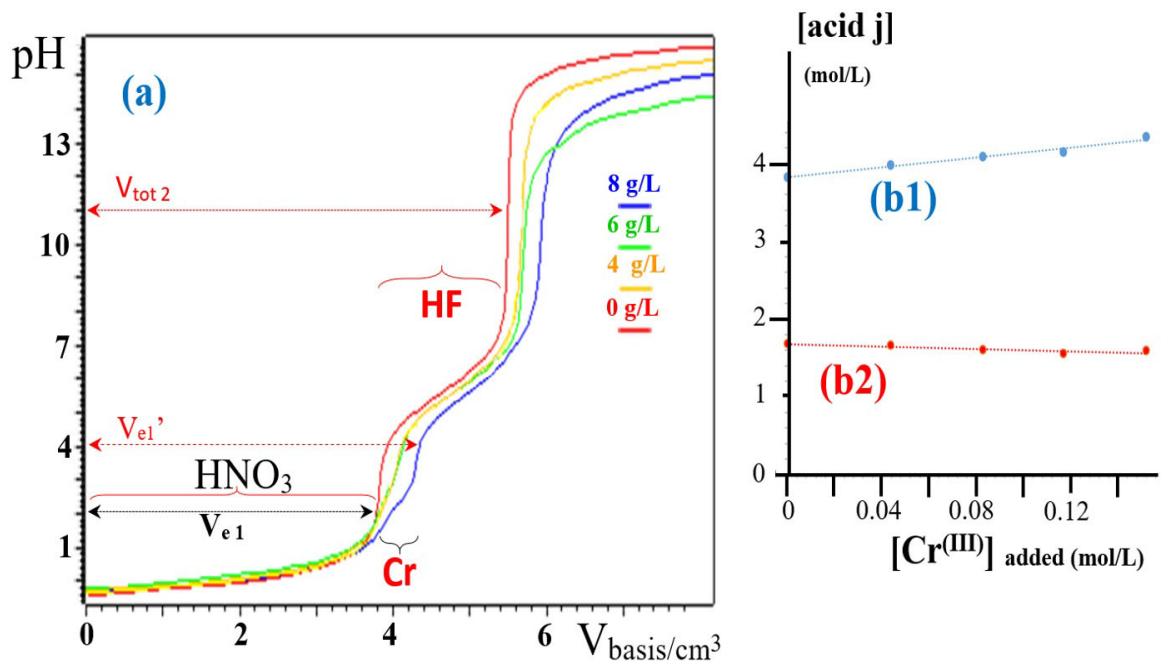

Figure 5. Acid-Base titration curves of the mixture containing $\mathrm{HNO}_{3}(3.8 \mathrm{~mol} / \mathrm{L}), \mathrm{HF}(1.7$ $\mathrm{mol} / \mathrm{L})$ and $\mathrm{Cr}\left(\mathrm{NO}_{3}\right)_{3}$ at various concentrations (a). $\mathrm{KOH}(1 \mathrm{M})$ is the titrating basis present in ethanol. Room temperature, agitation, Metrohm Toledo 888 titrator, solvotrode. Quantity of the solution to be titrated: $1 \mathrm{~mL}$, diluted in ethanol into a final volume of $50 \mathrm{~mL}$. Right: Effect of added $\mathrm{Cr}\left(\mathrm{NO}_{3}\right)_{3}$ concentration on the total acidity determined:

-(b1) from the neutralization volume $V_{\mathrm{eq} 1}^{\prime}$ :

$\left[\mathrm{HNO}_{3}\right]+\mu *\left[\mathrm{Cr}^{(\mathrm{III})}\right]=3.8+3.2 *\left[\mathrm{Cr}^{(\mathrm{III})}\right] R^{2}=0.97$

-(b2) from the neutralization volume $V_{\mathrm{eq} 2}-V_{\mathrm{eq} 1}^{\prime}$ :

$[\mathrm{HF}]+\eta *\left[\mathrm{Cr}^{(\mathrm{III})}\right]=1.7-0.7 *\left[\mathrm{Cr}^{(\mathrm{III})}\right] R^{2}=0.77$

Analysis of the titration curves leads to the following remarks:

- the $\mathrm{KOH}$ volume required for the first neutralization $\left(V_{\mathrm{e} 1}\right)$ remains practically constant versus the added $\mathrm{Cr}$ concentration, meaning that the presence of chromium does not affects the nitric acid neutralization wave.

- a new neutralization wave appears in second position ( $\mathrm{pH} 2$ ), and the corresponding "neutralization volume" $\left(V_{\mathrm{eq} 1}^{\prime}-V_{\mathrm{e} 1}\right)$ increase with the concentration of the added chromium; this wave is consequently attributed to the reaction of the added chromium with the potash.

- the third wave (previously attributed to the HF) shifts to the right (to the higher volumes of $\mathrm{KOH})$, however its volume $\left(V_{\mathrm{tot} 2}-V_{\mathrm{e} 1}^{\prime}\right)$ remains constant. These observations mean that, in the operating conditions, the presence of the chromium does not affect the neutralization volume of the HF; this implies a "no-strong complexation" between both species and is in agreement with the values of the equilibrium constants proposed in [17].

As the waves of $\mathrm{HNO}_{3}$ and $\mathrm{Cr}$ are very close, it is preferable to measure the overall volume of potash $\left(V_{\text {eq1 }}^{\prime}\right)$ used. Thus, the graph (b1) in Figure 5 present the total acidity neutralized during the first and the second wave (determined by the potash volume $V_{\mathrm{e} 1}^{\prime}$, i.e. nitric acid+chromium) versus the concentration of the added chromium. The slope of this curve $(\sim 3)$ correspond to the moles of potash used to neutralize the chromium added, consequently we propose the corresponding reaction: $\left(\mathrm{Cr}^{3+}+3 \mathrm{OH}^{-} \rightarrow \mathrm{Cr}(\mathrm{OH})_{3}\right)$. 
The graph (b2) in the same Figure 5 presents the acidity neutralized during the third wave (determined by the potash volume $V_{\mathrm{tot} 2}-V_{\mathrm{e} 1}^{\prime}$, i.e. hydrofluoric acid) versus the concentration of the added chromium. The obtained curve is practically a horizontal line (slope $\sim-0.7$ ) meaning that even if a complexation of the $\mathrm{Cr}^{3+}$ occurs by the fluoride, it is not strong enough to introduce significant error in the determination of the concentration of the HF.

From these results it can be proposed following equations:

moles of $\mathrm{KOH}$ used in both the $\mathrm{I}^{\text {st }}$ and $\mathrm{II}^{\mathrm{d}}$ neutralization $\left(V_{\mathrm{e} 1}^{\prime}\right)$

$=$ moles of $\mathrm{HNO}_{3}$ into the pickling bath titrated volume

$+3 \times$ moles of $\mathrm{Cr}^{(\mathrm{III})}$ introduced

moles of $\mathrm{KOH}$ used in the III ${ }^{\mathrm{d}}$ neutralization $\left(V_{\mathrm{e} 2}=V_{\mathrm{tot} 2}-V_{\mathrm{e} 1}^{\prime}\right)$

$=$ moles of the free HF into the pickling bath titrated volume.

Note that in the industrial pickling bath, the maximum concentration of the chromium cannot exceeds $0.08 \mathrm{~mol} / \mathrm{L}$, i.e. $4 \mathrm{~g} / \mathrm{L}$ (if yes the bath is renewed); if this maximum concentration is neglected (i.e. if $V_{\mathrm{e} 1}^{\prime}$ is totally attributed to the neutralization of the nitric acid) then the introduced error $(0.24 \mathrm{~mol} / \mathrm{L})$ reaches $6 \%$ of the initial concentration of the $\mathrm{HNO}_{3}$.

3) Influence of the nickel $\left(\mathrm{Ni}\left(\mathrm{NO}_{3}\right)_{3}, 9 \mathrm{H}_{2} \mathrm{O}\right)$ on the acid-base Titrations of a $\mathrm{HNO}_{3}, \mathrm{HF}$ pickling bath

The nickel is another metal present in significant quantities $\left(4<\mathrm{Ni}_{(\text {mass } \%)}<20\right)$ into the stainless steel alloys. As previously the influence of the nickel nitrate concentration on the volume of the titrating base $(\mathrm{KOH})$ required to neutralize $\mathrm{HNO}_{3}$ and $\mathrm{HF}$ was examined in order to determine if $\mathrm{Ni}^{(\mathrm{II})}$ cations released after the pickle of the alloy, are strongly complexed by the fluoride anions to form compounds such as $\mathrm{NiF}_{2}$, and the results were presented in Figure 6(a).

Analysis of the titration curves (a) leads to the following remarks:

- the $\mathrm{KOH}$ volume required for the first neutralization $\left(\mathrm{HNO}_{3}\right)$ remains constant versus the added $\left[\mathrm{Ni}^{(\mathrm{II})}\right]$. Indeed, curve $\mathrm{b} 1$ in the Figure 6 , corresponding to the added $\left[\mathrm{Ni}^{(\mathrm{II})}\right]$ dependence on the moles of $\mathrm{KOH}$ used for the first neutralization wave $\left(V_{\mathrm{el}}\right)$, appears as a straight line having a slope relatively low $(\sim-0.3)$, which could be considered as equal to zero;

- in a similar manner, the $\mathrm{KOH}$ volume required for the neutralizations occurring in the second part of the curve $\left(\mathrm{II}^{\mathrm{d}}\right.$ and $\mathrm{III}^{\mathrm{d}}$ waves, i.e. $\left.V_{\mathrm{e} 2}\right)$ remains practically constant versus the added $\mathrm{Ni}^{(\mathrm{II})}$ concentration. Indeed, curve $\mathrm{b} 2$ in the Figure 6, corresponds to the added $\left[\mathrm{Ni}^{(\mathrm{II})}\right]$ dependence on the moles of $\mathrm{KOH}$ used for the neutralizations of the $\mathrm{II}^{\mathrm{d}}$ and $\mathrm{III}^{\mathrm{d}}$ waves, also appears as a straight line having a slope of +0.2 , a value which could, in the operating conditions, be considered as equal to zero;

- the overall $\mathrm{KOH}$ volume $\left(V_{\mathrm{e} 1}\right.$ and $V_{\mathrm{e} 2}$ ) required for all neutralizations remains constant versus the quantity of the Nickel added;

- the third wave corresponds to the free HF neutralization;

- a new neutralization wave (a shoulder in fact), appears in second position $(\mathrm{pH} \sim 4)$ when $\mathrm{Ni}^{(\mathrm{II})}$ was added. The presence of a wave, coupled to the fact that 


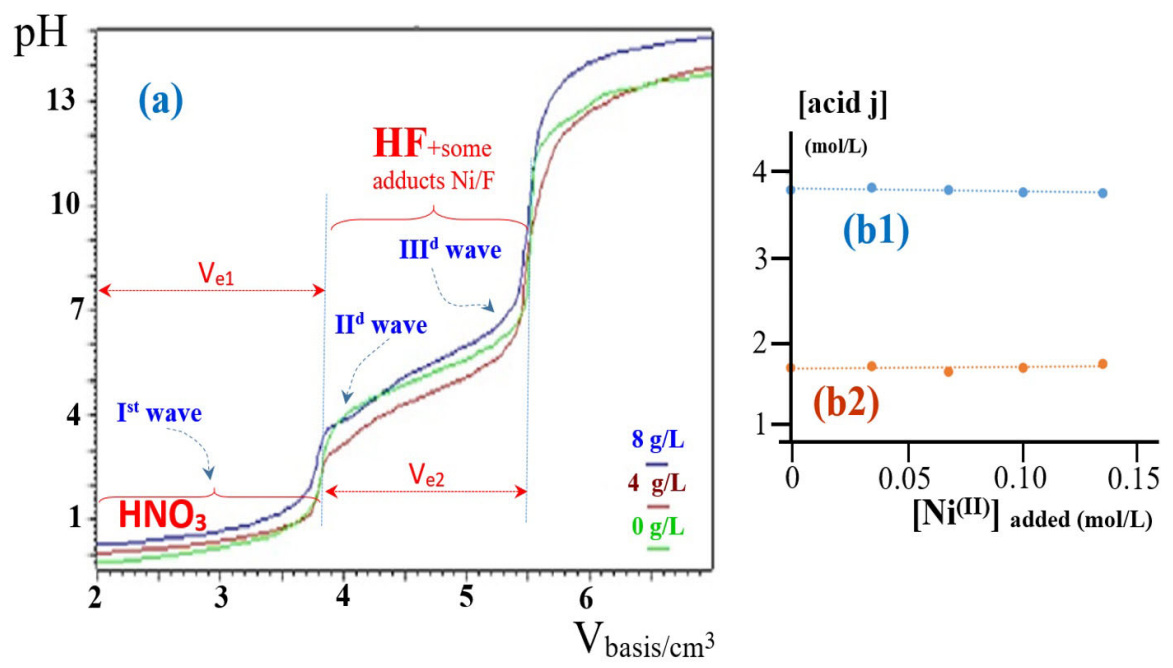

Figure 6. Acid-Base titration curves of the mixture containing $\mathrm{HNO}_{3}(3.8 \mathrm{~mol} / \mathrm{L}), \mathrm{HF}(1.7$ $\mathrm{mol} / \mathrm{L})$ and $\mathrm{Ni}\left(\mathrm{NO}_{3}\right)_{2}$ at various concentration (a). $\mathrm{KOH}(1 \mathrm{M})$ is the titrating basis present in ethanol. Room temperature, agitation, Metrohm Toledo 888 titrator, solvotrode. Quantity of the solution to be titrated: $1 \mathrm{~mL}$, diluted using ethanol into a final volume of $50 \mathrm{~mL}$. Right: Effect of added $\mathrm{Ni}\left(\mathrm{NO}_{3}\right)_{2}$ concentration on the total acidity determined: -(b1) from the neutralization volume $V_{\mathrm{el}}$ : [acidity] $=3.8-0.3 *\left[\mathrm{Ni}^{(\mathrm{II})}\right] R^{2}=0.7 \quad(\mathrm{e} 16)$. -(b2) from the neutralization volume $V_{\mathrm{e} 2}:[$ acidity $]=1.7+0.2 *\left[\mathrm{Ni}^{(\mathrm{II})}\right] R^{2}=0.2 \quad(\mathrm{e} 17)$.

the neutralization volume $\left(V_{\mathrm{e} 2}\right)$ remains practically constant, implies a possible complexation between HF and nickel (II). Two possibilities could be involved to explain this behavior: 1) a complexation occurs between HF and nickel (II), consuming $\mathrm{x} \mathrm{HF}$ and leading to a complex exhibiting $\mathrm{x}^{(+\mathrm{I})}$ to neutralize, without modification of the required volume of $\mathrm{KOH}$, and 2) $\mathrm{Ni}^{(\mathrm{II})}$ and HF react according to a more complicated equilibria. However, the equilibrium constants of all these reactions are low and during the titration of the HF, the equilibria shifts-back to regenerate the HF.

Moreover,

- the low resolution of this intermediate wave also confirms the low value of this equilibria. The following simple reactions could be proposed:

${ }^{*} \mathrm{Ni} / \mathrm{F}$ complexation: $\mathrm{Ni}^{2+}+x \mathrm{HF} \rightarrow \mathrm{H}_{x} \mathrm{NiF}_{x}^{2+}$;

${ }^{\star}$ first neutralization $\left(V_{\text {eq1 }}\right): \mathrm{HNO}_{3}+\mathrm{OH}^{-} \rightarrow \mathrm{H}_{2} \mathrm{O}+\mathrm{NO}_{3}^{-}$;

*second neutralization: $\mathrm{H}_{x} \mathrm{NiF}_{x}^{2+}+x \mathrm{OH}^{-} \leftrightarrows \mathrm{NiF}_{x}^{2-x}+x \mathrm{H}_{2} \mathrm{O}$;

*third neutralization: $\mathrm{HF}+\mathrm{OH}^{-} \rightarrow \mathrm{H}_{2} \mathrm{O}+\mathrm{F}^{-}$.

In these conditions a simple titration does not enables to determine a precise value for the coefficient $x$ (of $\mathrm{H}_{x} \mathrm{NiF}_{x}^{2+}$ ), even if it is obvious that the presence of $\mathrm{Ni}^{(\mathrm{II})}$ does not affects the volume required to titrate the HF (i.e. $x \sim 0$ ). In fact, the pickling bath were replaced when the concentration of $\mathrm{Ni}$ reaches a maximum of $0.068 \mathrm{~mol} / \mathrm{L}(4 \mathrm{~g} / \mathrm{L})$, and here the second wave appears only when the $\mathrm{Ni}$ concentration reaches $0.14 \mathrm{~mol} / \mathrm{L}(8 \mathrm{~g} / \mathrm{L})$ Figure $6(\mathrm{a})$.

Note that the precipitation of $\mathrm{Ni}(\mathrm{OH})_{2}$ was not observed in the operating conditions, because its high pK (around 6 in aqueous media, probably higher in 
ethanolic media).

Consequently, for the monitoring of the acidic content in the pickling bath, we can neglect the potash volume devoted to an eventual neutralization of the nickel cations, and following equations could be proposed:

$$
\begin{aligned}
& \text { moles of } \mathrm{KOH} \text { used in the } \mathrm{I}^{\text {st }} \text { neutralization }\left(V_{\mathrm{e} 1}\right) \\
& =\text { moles of } \mathrm{HNO}_{3} \text { into the pickling bath titrated volume }
\end{aligned}
$$

moles of $\mathrm{KOH}$ used in both the II $^{\mathrm{d}}$ and the III ${ }^{\mathrm{d}}$ neutralizations $\left(V_{\mathrm{e} 2}=V_{\mathrm{tot2}}-V_{\mathrm{e} 1}\right)$ (e19) $=$ moles of the free HF into the pickling bath titrated volume

Note that the other metallic cations released by the pickle of the stainless steels could be neglected, their mass percent remains low $(\leq 4 \%)$.

To sum up concerns the stainless steel alloys, taking into account the results of the titrations of the cations released by the pickle of the alloys, we propose the following way to monitor the concentrations of $\mathrm{HNO}_{3}$ and $\mathrm{HF}$ into the pickling bath:

To access to the nitric acid concentration, the following equation must be used:

$$
\begin{aligned}
& \text { moles of } \mathrm{HNO}_{3} \text { into the pickling bath titrated volume } \\
& =\text { moles of } \mathrm{KOH} \text { used in the first neutralization }\left(V_{\mathrm{e} 1}^{\prime}\right) \\
& -6 \times \text { moles of } \mathrm{Fe}^{(\mathrm{III})} \text { determined by ICP } \\
& -3 \times \text { moles of } \mathrm{Cr}^{(\mathrm{III})} \text { determined by ICP }
\end{aligned}
$$

To access to the hydrofluoric acid concentration, the following equation must be used:

$$
\begin{aligned}
& \text { moles of } \mathrm{HF} \text { into the pickling bath titrated volume } \\
& =\text { moles of } \mathrm{KOH} \text { used in the II }{ }^{\mathrm{d}} \text { neutralization }\left(V_{\mathrm{e} 2}=V_{\mathrm{tot2}}-V_{\mathrm{e} 1}^{\prime}\right)
\end{aligned}
$$

\subsection{Titration of Real Pickling Baths}

Several experiments were achieved to try to validate the above obtained results; typically, pickling of all the alloys indicated in the Table 1 were carried out using baths initially containing nitric acid and HF; titrations of each pickling bath were performed each 20 min during $2 \mathrm{~h}$ and simultaneously the above involved metallic cations were titrated by ICP. Results were compared to the mass loss of the alloy at the end of each pickle. As an example, typical values obtained with the alloy TA Table 1 agree with the stoichiometry of the reaction (R6) and confirm the validity/reliability of the method.

For another alloys, results (and specifically the evolution of the concentration of HF) appears coherent with the pickling rate of the alloy (the rate reaches zero for HF concentrations close to $0.3 \mathrm{M}$ ).

Note that for alloys containing zirconium, after pickling, it is observed into the bath precipitates attributed to the zirconium which does not oxidize at the operating conditions

Besides, it is impossible (in our knowledge) to absolutely validate the obtained 
results, e.g. the concentration of each acid, especially in presence of metallic cations; indeed most of the analytical available methods needs dilution, and this operation is able to modify the equilibria between the various species so to lead to erroneous results.

The proposed method is satisfactory because it takes account of the interfering metallic cations, as well as their contribution (stoichiometric factors on the neutralization reactions) on the potash volume required for the neutralization of both acids. The main drawback is that the determination of the metallic cations requires ICP, a relatively sophisticated and also expensive analytical method, even if it is required to analyze the metallic ions content before to regenerate, by various processes, the pickling bath for a new cycle [18] [19].

\section{Conclusions}

The content of the acids contained in the pickling bath used in the aeronautical industries must be monitored in order to ensure uniform pickle for all the treated pieces. Even if various methods were proposed in the bibliography, the results were not reliable and sometimes strong dispersion can be observed between the results of sub-contracting operators. In the present study, acid-basis titration by potash, monitored by $\mathrm{pH}$ metry, was chooses and a systematic analysis of the effect of the metallic cations "in majority into the alloys" was carried out, into the ethanol in order to limit the precipitation of the metallic hydroxides. The $\mathrm{pH}=\mathrm{f}\left(\mathrm{V}_{\mathrm{KOH}}\right)$ curve obtained with an initial composition bath, exhibits two waves respectively attributed to the neutralization of nitric and hydrofluoric acids. In general, the pickling of the alloys produces cations which were complexed by fluoride ions and the resulting adducts behave as acids, able to be neutralized by $\mathrm{KOH}$ in a similar way as $\mathrm{HNO}_{3}$ and $\mathrm{HF}$.

For the titanium alloys, results clearly demonstrates interferences (on the neutralization curve) with the $\mathrm{Ti}^{(\mathrm{IV})}$ and $\mathrm{Al}^{(\mathrm{III})}$ while for stainless steels alloys interferences were observed with iron and chromium: all these cations complexes with fluoride, thus consuming HF. A possibility to simplify the titration is to use separated bath to pickle the titanium and the stainless steel alloys.

To deduce the concentration of the hydrofluoric acid, the $\mathrm{KOH}$ volume used to neutralize the second wave of the curve $\mathrm{pH}=\mathrm{f}\left(\mathrm{V}_{\mathrm{KOH}}\right)$, can be directly used i.e. Equation (e6) for the titanium alloys and (e21) for the stainless steel alloys. Note that the $\mathrm{V}_{\text {КОН }}$ can be disturbed by the neutralization of the nickel cations: here we neglect this species because: 1) the shoulder indicating the presence of nickel appears on the curve for contents of nickel higher than the maximum that is possible to reach for the highest time life of the bath; and 2) the nickel fluoride complex appears to have a low stability constant.

The determination of the concentration of the nitric acid is more complicated, as two metallic ions (per family of alloys) interfering on the neutralization of the first wave; indeed at the least three metallic cations $\left(\mathrm{Ti}^{(\mathrm{IV})}, \mathrm{Al}^{(\mathrm{III})}\right.$ and $\left.\mathrm{Fe}^{(\mathrm{III})}\right)$ complexes with fluoride and produces strong acids which neutralize simultaneously 
with nitric acid! In addition, neutralization of $\mathrm{Cr}^{(\mathrm{III})}$ by $\mathrm{OH}^{-}$was also observed near the first neutralization. To overcome this drawback, it is proposed to use ICP to determine the concentrations of the cations such as iron and chromium for stainless steel alloys and titanium and aluminum for titanium alloys. Then titration of the pickling bath by $\mathrm{KOH}$ provide the curve $\mathrm{pH}=\mathrm{f}\left(\mathrm{V}_{\mathrm{KOH}}\right)$, of which the potash volume used to neutralize the first wave enables to access to $\mathrm{HNO}_{3}$ content, thanks to the established Equations (e5) for the titanium alloys and (e20) for the stainless steel alloys.

\section{Acknowledgements}

The authors would like to thank the airbus company and also the UT-III-PS for financing this study. Thanks are also due to François Bléhaut for its significant investment in the project.

\section{References}

[1] Bahadori, A. (2015) Essentials of Coating, Painting, and Lining for the Oil, Gas and Petrochemical Industries. In: Surface Preparation for Coating, Painting, and Lining, Chapter 1, Elsevier, Amsterdam, 1-105.

[2] Kladnig, W.F. (2008) New Development of Acid Regeneration in Steel Pickling Plants. Journal of Iron and Steel Research International, 15, 1-6. https://doi.org/10.1016/S1006-706X(08)60134-X

[3] Sutter, E.M.M. and Goetz-Grandmont, G.J. (1990) The Behavior of Titanium in Nitric-Hydrofluoric Acid Solutions. Corrosion Science, 30, 461-476. https://doi.org/10.1016/0010-938X(90)90051-6

[4] Say, W.C. and Tsai, Y.Y. (2004) Surface Characterization of Cast Ti-6Al-4V in Hydrofluoric-Nitric Pickling Solutions. Surface and Coatings Technology, 176, 337-343. https://doi.org/10.1016/S0257-8972(03)00747-3

[5] Schneiker, T. and Forsberg, K. (2014) Process Chemistry and Acid Management in Titanium Pickling Processes. Conference on Titanium Europe, Sorrento, 19-21 May 2014.

[6] Steinert, M., Acker, J., Oswald, S. and Wetzig, K. (2007) Study on the Mechanism of Silicon Etching in $\mathrm{HNO}_{3}$-Rich $\mathrm{HF} / \mathrm{HNO}_{3}$ Mixtures. The Journal of Physical Chemistry $C, 111,2133-2140$. https://doi.org/10.1021/jp066348j

[7] Tongwen, X. and Weihua, Y. (2003) Industrial Recovery of Mixed Acid (HF + $\mathrm{HNO}_{3}$ ) from the Titanium Spent Leaching Solutions by Diffusion Dialysis with a New Series of Anion Exchange Membranes. Journal of Membrane Science, 220, 89-95. https://doi.org/10.1016/S0376-7388(03)00218-7

[8] Cros, C. and Bares, P. (2012) Procédé de régénération d'une solution de décapage ou d'usinage chimique de titane. French Patent, EP2438210A1.

[9] Hermoso, J., Dufour, J., Gálvez, J.L., Negro, C. and López-Mateos, F. (2005) Nickel Hydroxide Recovery from Stainless Steel Pickling Liquors by Selective Precipitation. Industrial \& Engineering Chemistry Research, 44, 5750-5756. https://doi.org/10.1021/ie050422n

[10] Gálvez, J.L., Dufour, J., Negro, C. and López-Mateos (2006) Fluoride Speciation in Stainless Steel Pickling Liquor. ISIJ International, 46, 281-286. https://doi.org/10.2355/isijinternational.46.281

[11] Gumin, K., Kwangchil, L., Haesung, P., Jinho, L., Youngjean, J., Kyoungsik, K., 
Boongho, S. and Hyoungkuk, P. (2010) Quantitative Analysis of Mixed Hydrofluoric and Nitric Acids using Raman Spectroscopy with Partial Least Squares Regression. Talanta, 81, 1413-1417. https://doi.org/10.1016/j.talanta.2010.02.045

[12] Gumin, K., Kwangchil, L., Haesung, P., Jinho, L., Youngjean, J. and Kyoungsik, K. (2010) Optical Measurement for the Concentrations of the Pickling Acid with Near Infrared Spectroscopy in Steel Making Industry. SPIE Proceedings, 7792, 77920 G.

[13] Lindroos, K. (1987) Determination of Free Hydrofluoric and Nitric Acids in Pickling Bath Liquors using a Fluoride-Selective Electrode and Alkalimetric Titration. Analyst, 112, 71-73. https://doi.org/10.1039/an9871200071

[14] Gálvez, J.L., Dufour, J., Negro, C. and López-Mateos, F. (2009) Routine to Estimate Composition of Concentrated Metal-Nitric-Hydrofluoric Acid Pickle Liquors. $\mathrm{Hy}$ drometallurgy, 96, 88-94. https://doi.org/10.1016/j.hydromet.2008.08.007

[15] Gong, W.X., Qu, J.-H., Liu, R.-P. and Lan, H.-C. (2012) Effect of Aluminum Fluoride Complexation on Fluoride Removal by Coagulation. Colloids and Surfaces A: Physicochemical and Engineering Aspects, 395, 88-93.

https://doi.org/10.1016/j.colsurfa.2011.12.010

[16] Gálvez, J.L., Dufour, J., Negro, C. and López-Mateos, F. (2008) Determination of Iron and Chromium Fluorides Solubility for the Treatment of Wastes from Stainless Steel Mills. Chemical Engineering Journal, 136, 116-125.

https://doi.org/10.1016/j.cej.2007.03.014

[17] Seigneur, C. and Constantinou, E. (1995) Chemical Kinetic Mechanism for Atmospheric Chromium. Environmental Science Technology, 29, 222-231. https://doi.org/10.1021/es00001a029

[18] Regel-Rosocka, M. (2010) A Review on Methods of Regeneration of Spent Pickling Solutions from Steel Processing. Journal of Hazardous Materials, 177, 57-69. https://doi.org/10.1016/j.jhazmat.2009.12.043

[19] Ghare, N.Y., Wani, K.S. and Patil, V.S. (2013) A Review on Methods of Recovery of Acid(s) from Spent Pickle Liquor of Steel Industry. Journal of Environmental Science \& Engineering, 55, 253-266. 